U.D.C. $547.53-023: 542.92$

\title{
アルキルベンゼンの接触分解 $\quad(\mathrm{I}, \mathbb{I})$
}

——昭和 30 年 11 月 9 日受理一一

大阪大学工学部 堤 繁·赤塚 寿·森村恭郎・多賀浩二

要旨：一(その1) キューメンの接触分解を銅ークロム触媒を用い，500～700 $\mathrm{C}, 300 \sim 500 \mathrm{~m}-$ $\mathrm{mHg}$ の減圧下で試みた。スタイレンの生成浪溫度と共に篔大するが， $\alpha$ ーメチルスタイレンは $630 \sim 650^{\circ} \mathrm{C}$ 心最高收量を得, 以後却つて減少した。工業的にスタイレンおよび $\alpha$ ーメチル スタイレンを主として阷造する場合の最適條件を決定した。またスタイレンおよび $\alpha$ チチル スタイレンの分析法を比較してブロマイド法が最適ですることを認めた。

（その 2）同様にp-サイメンの接触分解をも銅ーク口ム触媒を用い, $600 \sim 700^{\circ} \mathrm{C}, 500 \mathrm{mmHg}$

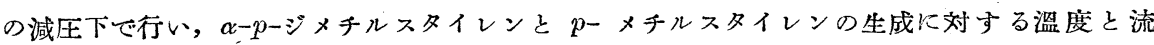
速の影響を検討した。その結果, 溫度高く, 流速小なる程分解率々大となる。脫水素反応す なわち $\alpha-p$-ジメチルスタイレンの生成は比較的低溫で扣こり流速の大なるほぞよく，㧤メタ ン反応すなわち $p$-メチルスタイレンの生成な此較的高溫で报てり，流速ね小なるほどよい。 また銅ークロム触媒な䏯水素用よりも脫メタン用としてすぐれているととなどを認めた。

（その1）キューメンの接触分解によ るスタイレン同族体の合成

キューメンは硫酸の存在の下にベンゼンと石油分解 ガス中のプロピレンとを反応させることにより容易に 合成できる。たとえばベンゼン $443 \mathrm{cc}(5 \mathrm{~mol})$ ，硫酸 (84\%) $156 \mathrm{cc}$ の混合物を $45^{\circ} \mathrm{C}$ に保ち摫拌し年ら石油 分解ガスを通すと，反応したプロピレンに詨し $81.6 \%$ の収量でキューメンが合成されだ1。

キューヌンの利用法としては, これをフェフールに か劣ることも考えられるが，またこれよりスタイレン 同族体に変化させることも一つの方法である。

本報告はキューメンの接触分解によりスタイレンお よび $\alpha$ タチルスタイレンの合成実験を行つた結果で ある。

キューメンを熱分解すれば，次の 3 つの反応がおこ り得る。

(1)<smiles>CCC=Cc1ccc(C(C)C)cc1</smiles>

(2)<smiles>CC=Cc1ccc(C(C)C(C)c2ccccc2)cc1</smiles>

(3)<smiles>C=C(c1ccc(C(C)C)cc1)C(C)C</smiles>

しかしてこれらの反応の場合の恒圧平衡恒数 $K_{\boldsymbol{q}}$ と 温度 $T$ との関係は次式で表わされる2)。

(1)式 $-\log K_{p}=\frac{8900}{4.573 T^{T}}-1.75 \log T-2.78$

(2)式 $-\log K_{p}=\frac{26300}{4.573 T^{T}}-1.75 \log T-2.78$

(3)式 $-\log K_{p}=\frac{25300}{4.573 T^{T}}-1.75 \log T-1.60$

これらの式から計算した変化率の温度による変化は 第 1 図に示すごとくで, 大体 $800^{\circ} \mathrm{K}\left(527^{\circ} \mathrm{C}\right)$ 以上で, 3 つの反応とも $90 \%$ 以上の変化率を示すものと推定 される。

著者らはさきにエチルベンゼンの脱水素によるスダ イレンの合成を，銅一クロム触媒を用い，減圧下にて 実施し良収量を以てスタイレンを合成し得たが3)，本 研究に抢いてもこれとほぼ類似の條件の下にキュー メンの接触分解を行つた。

\section{I. 原料}

ベンゼンと石油分解ガスとより前述の方法によつて 
第 1 図 理論変化率

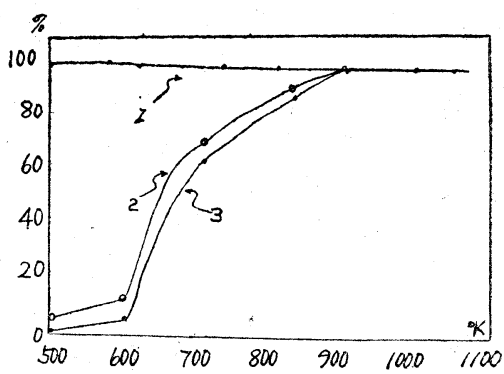

得たもので, 精溜を繰返し, 原料キューメンを調製し た。その物理恒数は次のごとくである。

$$
\begin{array}{lll}
\text { b.p. } & 152 \sim 153^{\circ} \mathrm{C} & d_{4}^{20} 0.8621 \\
n_{D}^{20} & -1.4915 & \text { 臭素価 } 0.1
\end{array}
$$

また触媒は前報るに述べたと同様にして調製した銅一 クロム触媒を用いた。

\section{II. 実験裝置および方法}

前報3)エチルベンゼンの脱水素に用いたものとほほ 同椂である。

\section{III. 分析方法}

キューメンの接触分解によつて得られる可能性の西 るものの沸点は次のごとくである。

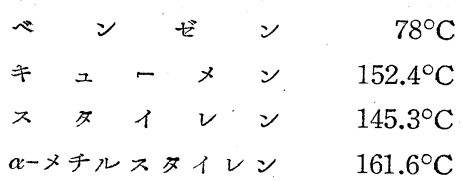

すなわち沸点差の最も少いのは末反応キューメンと スタイレンで, $7.1^{\circ} \mathrm{C}$ の差しかない。精溜によつて分 けるためには 30 段以上の精溜塔が必要で，しかも蒸 溜中の損失も考光る必要があり, 従つてこれら生成物 の分析は蒸溜によらず，次の方法を検討した。

（A） 精溜法：反応生成物を 36 段のステッドマン 式精溜塔学用い，還流比 $10: 1$ 位で蒸溜を試みた。 その結果は第 2 四のごとくである。

第 2 図 生成物の蒸溜（実験17）

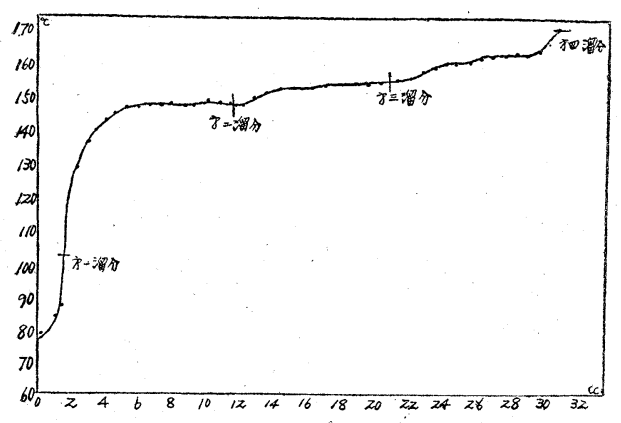

次に各溜分につき，臭素価を次のごとくにして測定 した。

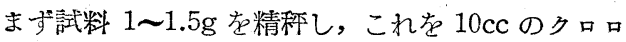
ホルムにとかし，氷で泠却し乍ら徐々に臭素液を滴下 しわずかに着色した所で止めて，10 $\mathrm{mmHg}$ の減圧 下で,クロロホルムおよび飽和炭化水素類を除去す る。このときスタイレンが存在すれば結晶が柝出し, ๙ーメチルスタイレンは液状催涙性の臭化物として残 る。得られたスタイレンの臭化物の結晶は m.p. $74^{\circ} \mathrm{C}$ で も交献值と一致する。

この方法により第 2 図に示した各溜分の組成を分析 した結果は第 1 表に示すごとくである。

\begin{tabular}{|c|c|c|c|c|c|c|c|}
\hline \multirow[b]{2}{*}{ 溜分 $\left({ }^{\circ} \mathrm{C}\right)$} & \multicolumn{2}{|l|}{ 重 } & \multirow{2}{*}{$\begin{array}{l}\text { 臭 } \\
\text { 素 }\end{array}$} & \multicolumn{2}{|c|}{$\begin{array}{c}\text { 臭素価上 } \\
(\%)\end{array}$} & \multicolumn{2}{|c|}{$\begin{array}{c}\text { ブロマイ } \\
\text { F゙法より } \\
(\%)\end{array}$} \\
\hline & $\frac{\text { 量 }}{\mathrm{g}}$ & $n \underset{D}{20}$ & & $\begin{array}{l}\text { त } \\
\text { 及 } \\
1 \\
2\end{array}$ & $\begin{array}{l}\alpha-x \\
\text { チл } \\
\pi \text { 及 } \\
12\end{array}$ & $\begin{array}{l}\pi \\
3 \\
1 \\
2\end{array}$ & $\begin{array}{l}\alpha-x \\
\text { チル } \\
\text { スタ } \\
\text { 1⁄ }\end{array}$ \\
\hline $70 \sim 102$ & 1.1 & 1.5010 & 1.3 & 1.0 & - & - & - \\
\hline $102 \sim 148$ & 8.6 & 1.5195 & 77.7 & 50.4 & - & 50.0 & - \\
\hline 148 154 & 8.6 & 1.4987 & 20.3 & 13.3 & - & 11.0 & - \\
\hline $154 \sim 170$ & 8.4 & 1.5272 & 98.7 & - & 73.0 & - & 80.1 \\
\hline 残 渣 & 6.4 & - & - & - & - & - & - \\
\hline 失 & 3.9 & - & - & - & - & - & - \\
\hline
\end{tabular}

\section{第 1 表 生成物（实験17）の組成}

但しブロマイド法は後述の (B)法によつたもので， 莫素価の值より計算したものとかなりの開きがある。

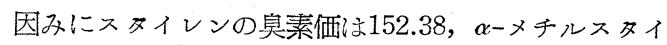
レンのそ礼は 135.5 である。つて本実験はこの方法 を採用することを止め，次のブロマイド法によつた。

（B）ブロマイド法：この方法は精溜を行わず，減 圧下でヌール分を除去した試料 1〜2g を精科し，10 cc のクロロホルムにとかし, 水水で冷却し乍ら少し 着色するまで具素液を滴下し, 後 $15 \mathrm{mmHg}$ の減压, $40^{\circ} \mathrm{C}$ 以下の條件でクロロホルム抢よび飽和炭化水素 を除く。もしスタイレンが存在すれば(A)に述べたご とくスタイレンジブロマイドの結晶が㭛出するが， $\alpha-$ メチルスダイレンが共存すると液状となる。これに80 \%アルコールを加えると $\alpha$ メキルジブロムスタイレ ンはアルコールに不溶のため, 2 層に別れる。アルコ ールが少いと，スタイレンジブロマイドが下層の $\alpha-$ メチルジブロムスタイレンに相当溶解するため, 順次 アルコールを加え, 下層の液量が不変となるまで行 う。約 $3 \mathrm{hr}$ 放置してから, 分液漏斗て禹液を分離し, 上のアルコール層は $10 \mathrm{mmHg}$ 内外の減压下で濃縮 
し，承水で冷却するとスタイレンジブロマイドが㭛出 する。これを科量しだガラス漏斗をとおし，さらに濃 縮結晶化をくりか方。約 4 回行つてからガラス漏斗 上の結晶を 1 昼夜デシケーター中で乾燥してから科量 し，スタイレンの量を定量訫算寸る。一方全体の臭素 価を測定して批て，両方の值から $\alpha$-メテルスタイ レンの量を算出する。下層の $\alpha$-メチルスタイレンの ジブロマイドの液は相当アルコールを含んでいるの で，これを秤量して定量することは危険である。

生じた結晶は $74^{\circ} \mathrm{C} の \mathrm{~m} . \mathrm{p}$. て交献值と一致するが $\alpha$-メチルジブロムスタイレンの比重は 1.601 で文献 の 1.641 より小さい。これはアルコールを少量含んで いるためと思われる。

第 2 表はこの分析法の精確度を検するため，純粋な 各成分を混合してこの分析法で分析した結果である。

\section{第 2 表 プロマイド法の精確度}

\begin{tabular}{|c|c|c|c|c|c|c|c|}
\hline \multicolumn{3}{|c|}{ 標準試料(\%) } & \multirow{2}{*}{ 臭 } & 試 & 䊅 & \multirow{2}{*}{$\begin{array}{l}\text { z } \\
\text { 夕 }\end{array}$} & \multirow[t]{2}{*}{ 偏 } \\
\hline$\neq$ & z & $\alpha-x$ & & & & & \\
\hline$\frac{7}{1}$ & タ & チル & 素 & 料 & & 2 & 差 \\
\hline$x$ & $\begin{array}{l}1 \\
2\end{array}$ & 12 & 価 & g & $\frac{\text { 黑 }}{g}$ & 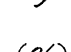 & \% \\
\hline 00.0 & $\begin{array}{l}\text { y } \\
0.0\end{array}$ & " 0.0 & 0.8 & $\stackrel{\text { ह }}{1.8224}$ & $0^{8}$ & $\begin{array}{l}(\%) \\
0\end{array}$ & 0 \\
\hline 62.0 & 38.0 & 0.0 & 58.5 & 2.0714 & 1.2714 & 36.1 & -1.9 \\
\hline 48.8 & 20.4 & 30.8 & 72.9 & 1.5212 & 1.4887 & 18.9 & -1.1 \\
\hline 40.2 & 13.5 & 46.3 & 83.9 & 2.2260 & 0.5825 & 15.5 & +2.0 \\
\hline 34.2 & 0.0 & 65.8 & 89.0 & 1.8874 & 0 & 0 & 0 \\
\hline
\end{tabular}

大体 1〜2\% の偏差で一致する。本研究では主とし てこの方法を用いた。

(C) 塩化水素法 (Elliot 法) ${ }^{4}$ : これは塩酸と区 応させて次の化合物をつくり, 両者間の加水分解速度 の相違に基いている。<smiles>CC(Cl)c1ccc(Cl)cc1</smiles><smiles>C=C(C)c1ccccc1</smiles>

（2）の生成物が(1)のそれに比べ加水分解の速度が 早いことを利用するのであるが，標準試料の混合物を つくつてその分析法の精確度を検したが, 本研究の目 的には不適当であつた。

\section{IV. 実駼結果}

内径 $2 \mathrm{~cm}$, 長さ $1 \mathrm{~m}$ の石英管中に $65.0 \mathrm{~g}(83.4 \mathrm{cc})$ の銅ークロム触媒の成型したものを長さ $26.5 \mathrm{~cm}$ の間 に充填し，毎回 $50 \mathrm{cc}(43 \mathrm{~g})$ の手ューメンを用いて行 つた結果は第 3 表に示すごとくである。但し流速は触 媒 $1 \mathrm{cc}$ 当りの原料キューメンの毎時の送入 $\mathrm{cc}$ を表わ
す。

以上の結果を基として考察を試みてみる。

(A) 流速-変化率 第 3 図は流速 $(\mathrm{cc} / \mathrm{hr})$ と変化 率との関係を示すもので，変化率は $600^{\circ} \mathrm{C} て ゙ は$ 余り大

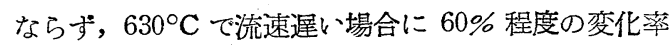
に急増し，650〜 $670^{\circ} \mathrm{C}$ では $70 \%$ 以上に達し， $700^{\circ} \mathrm{C}$ では急激に増加する。

第 3 図 溫度-流速-变化率の関係

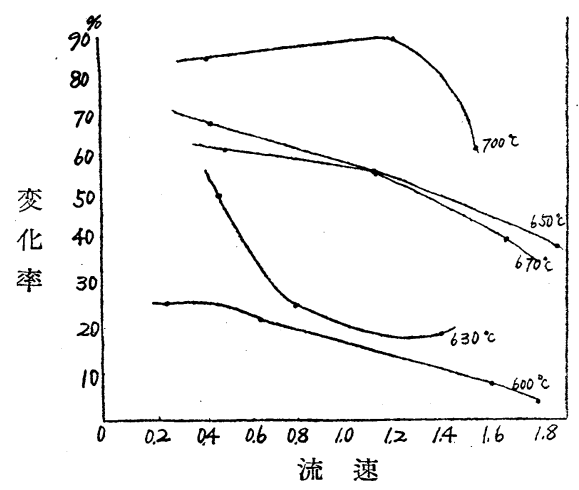

(B) 流速-温度-宄極収率

今流速 $0.5,1.0$ および $1.5 \mathrm{cc} / \mathrm{hr}$ の場合の温度によ る変化率の相違を示すと第 4 図のごとくであり，これ をスタイレンおよび $\alpha$ をチルスタイレンに区别して 図示すると第5〜6図のごとくで $\alpha$ メチルスタイレン の生成は $650^{\circ} \mathrm{C}$ 附近で最大值を示すのに対し，スタイ レンの生成は $600 \sim 700^{\circ} \mathrm{C}$ では温度の上昇と共に増加 している。従つて第 4 図のような曲線は第5〜6図が綜 合されて，このような曲線となつたものと思われる。

\section{第 4 図、流速-溫度-变化率の関係}

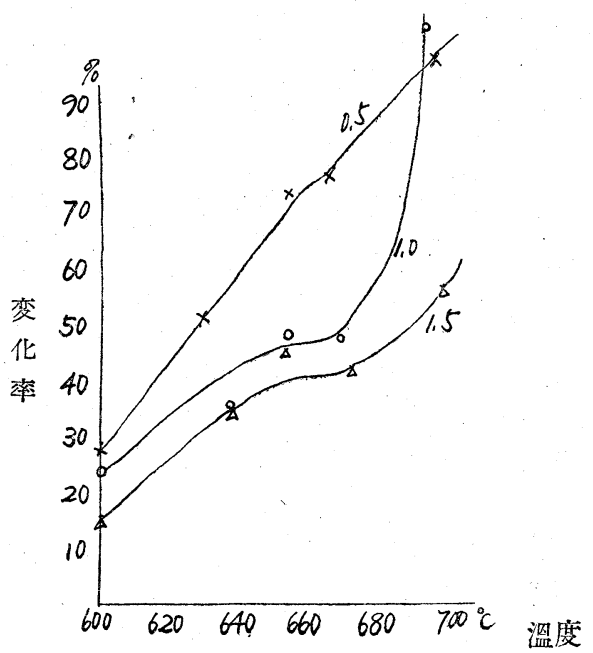

（図中の数字注触媒1 $1 \mathrm{cc}$ 当りの流速 $\mathrm{cc} / \mathrm{hr}$ を示す） 
第3表 銅-ク口ム触媒による

\begin{tabular}{|c|c|c|c|c|c|c|c|c|c|c|}
\hline 番 & 溫 & 圧 & 流 & ガ & & ガ & $\pi$ & 且 & $(\%)$ & \\
\hline 号 & $\begin{array}{c}\text { 慶 } \\
\left({ }^{\circ} \mathrm{C}\right)\end{array}$ & $\underset{\mathrm{mmHg}}{\text { 力 }}$ & $\begin{array}{l}\text { (cc/ }{ }^{\text {速 }} \\
\text { cchrs) }\end{array}$ & 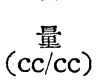 & $\mathrm{CO}_{2}$ & H.H.C. & $\mathrm{C}_{2} \mathrm{H}_{4}$ & $\mathrm{CO}$ & $\mathrm{H}_{2}$ & \\
\hline 1 & 500 & 100 & 1.130 & 7.4 & 0 & 1.4 & 2.2 & 2.8 & 62.3 & \\
\hline 2 & 500 & 300 & 0.478 & 9.0 & 0 & 1.8 & 0.6 & 0.4 & 66.0 & \\
\hline 3 & 600 & 20 & 0.995 & 9.3 & 0 & 4.0 & 1.0 & 2.4 & 60.5 & \\
\hline 4 & 600 & 300 & 0.317 & 9.0 & 0 & 1.8 & 0.6 & 2.9 & 65.4 & 28. \\
\hline 5 & 600 & 400 & 0.580 & 22.0 & 0 & 1.2 & 0.4 & 3.2 & 60.2 & \\
\hline 6 & 600 & 500 & 1.585 & 10.6 & 0 & 1.4 & 0.0 & 1.8 & 58.1 & 37 \\
\hline 7 & 600 & 500 & 0.635 & 24.0 & 0 & 1.8 & 2.0 & 2.0 & 56.5 & 37. \\
\hline 8 & 600 & 500 & 0.217 & - & 0 & - & - & - & - & \\
\hline 9 & 630 & 500 & 1.430 & 37.3 & 0 & 4.0 & 1.6 & 1.6 & 57.0 & 36 \\
\hline 10 & 630 & 500 & 0.795 & 6.5 & 0 & 3.6 & 2.0 & 1.8 & 58.0 & 35. \\
\hline 11 & 630 & 500 & 0.410 & 6.5 & 0 & 3.2 & 3.0 & 4.0 & 52.2 & 37 . \\
\hline 12 & 650 & 300 & 0.397 & 13.0 & 0 & 2.6 & 4.8 & 5.6 & 44.2 & 33. \\
\hline 13 & 650 & 400 & 0.288 & 10.0 & 0 & 2.2 & 2.4 & 4.8 & 45.0 & 40. \\
\hline 14 & 650 & 500 & 1.727 & 4.0 & 0 & 2.6 & 2.4 & 3.8 & 47.1 & 44 \\
\hline 15 & 650 & 500 & 0.952 & 9.2 & 0 & 2.8 & 3.2 & 6.8 & 43.2 & 34. \\
\hline 16 & 650 & 500 & 0.329 & 21.4 & 0 & 2.0 & 2.2 & 0.0 & 51.6 & 44 \\
\hline 17 & 670 & 300 & 0.720 & 13.7 & 0 & 3.5 & 2.8 & 5.2 & 36.1 & 52. \\
\hline 18 & 670 & 400 & 0.433 & 16.0 & 0 & 2.8 & 6.0 & 3.2 & 39.0 & 48.1 \\
\hline 19 & 670 & 500 & 1.585 & 9.0 & 0 & 4.6 & 2.8 & 3.8 & 38.8 & 50. \\
\hline 20 & 670 & 500 & 0.955 & 18.0 & 0 & 2.0 & 3.6 & 4.2 & 38.4 & 51. \\
\hline 21 & 670 & 500 & 0.397 & 12.4 & 0 & 3.0 & 6.2 & 2.4 & 39.4 & 49. \\
\hline 22 & 700 & 200 & 0.373 & 15.3 & 0 & 2.4 & 6.4 & 2.0 & 39.0 & 59. \\
\hline 23 & 700 & 300 & 1.880 & - & 0 & 2.0 & 3.6 & 1.6 & 30.4 & 62 \\
\hline 24 & 700 & 300 & 0.381 & 20.5 & 0 & 2.6 & 7.8 & 3.0 & 20.6 & 66. \\
\hline 25 & 700 & 500 & 1.400 & 15.3 & 0 & 3.4 & 5.2 & 2.0 & 29.2 & 60. \\
\hline 26 & 700 & 500 & 0.953 & 22.5 & 0 & 2.8 & 1.6 & 3.6 & 30.0 & 62 \\
\hline 27 & 700 & 500 & 0.407 & 15.4 & 0 & 3.4 & 3.6 & 3.0 & 30.2 & \\
\hline
\end{tabular}

\section{第 5 図 溫度一流速による $\alpha$-メチル スタイレンの收率変化}

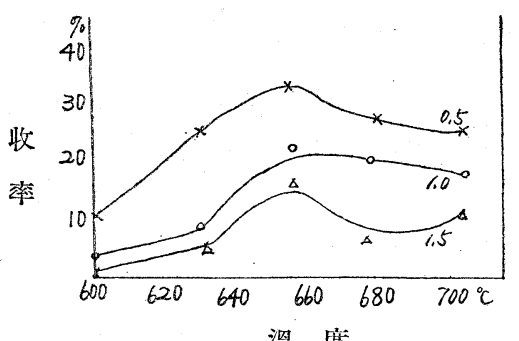

溫 度

（図中の数字汶触媒1cc当 りの流速cc/hrを示す)
第 6 図 溫度一流速によるスタイレ ンの收率変化

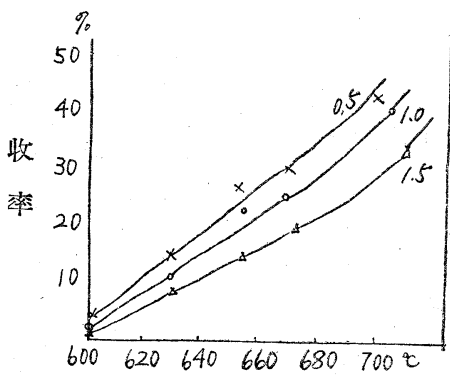

溫 度

（図中の数字々触媒 $1 \mathrm{cc}$

当りの流速cc/hrを示す)
は $630^{\circ} \mathrm{C} て ゙ 51.0 \%$ (実験 10 ) であつた。

また反応後无スのメタ ン，水素の量から訫算した驱 率曲線も第 7〜8 図に大体一 致した。

\section{$\mathrm{V}$. 反応生成物の性状}

上記の諸実験で得たスタイ レン並に $\alpha$-メチルスタイレ ンの性状を示すと，第 4 表の ごとくである。

VI. 従来の研究との比較

岩井氏2)はキューメンに2
第 7〜8図はスダイレンおよび $\alpha$-メテルスタイレン の究極収率（反応したキューメンに詨寸る wto）を 示すものである。その最高収量はスタイレンの場合 $700^{\circ} \mathrm{C}$ で $51.4 \%$ (赛験 22 ), また $\alpha$-メチルスタイレン
倍量の水蒸気を添加し，第 5 表に示すような触媒を用

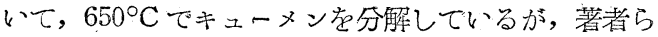

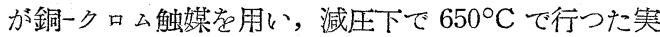
験 12〜16 と比較すると，一般的にスタイレンよりも 
キューメンの接触分解

\begin{tabular}{|c|c|c|c|c|c|c|c|c|c|}
\hline \multirow[b]{2}{*}{ 色 } & 生 & ブ & 変 & 收 & 綷 (\%) & 究極收 & 率 $(\%)$ & スタイレシ & \\
\hline & 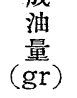 & $\begin{array}{l}\text { 口 } \\
\text { 厶 } \\
\text { 価 }\end{array}$ & $\begin{array}{l}\text { 化 } \\
\text { 率 } \\
(\%)\end{array}$ & $\begin{array}{l}\text { スタイレ } \\
\text { ン }\end{array}$ & $\begin{array}{l}\alpha-x チ ル ~ \\
\text { スタイレ } \\
\text { ン }\end{array}$ & $\begin{array}{l}\text { スタイレ } \\
\text { ン }\end{array}$ & $\begin{array}{l}\alpha-x チ ル ~ \\
\text { スタイレ } \\
\text { ン }\end{array}$ & 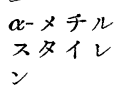 & $\mathrm{CH}_{4} / \mathrm{H}_{2}$ \\
\hline 淡黃 & 46.0 & 2.42 & 3.0 & - & - & - & - & - & 0.487 \\
\hline$"$ & 40.0 & 2.50 & 3.0 & - & - & - & - & - & 0.470 \\
\hline " & 42.5 & 4.24 & 2.5 & - & - & - & - & - & 0.493 \\
\hline " & 48.1 & 4.58 & 2.8 & - & - & - & - & - & 0.434 \\
\hline " & 40.0 & 22.5 & 22.0 & 5.0 & 10.1 & 22.7 & 45.9 & 0.495 & 0.547 \\
\hline " & 39.0 & 8.5 & 14.6 & 2.5 & 3.5 & 17.2 & 24.2 & 0.715 & 0.650 \\
\hline$"$ & 39.0 & 20.4 & 23.7 & 4.0 & 10.0 & 17.4 & 25.0 & 0.400 & 0.666 \\
\hline " & 39.0 & 23.1 & 24.2 & - & 11.8 & 16.7 & 29.5 & 0.339 & - \\
\hline 茶褐 & 39.0 & 26.6 & 25.6 & 7.0 & 12.5 & 27.4 & 48.9 & 0.560 & 1.642 \\
\hline$"$ & 39.0 & 30.2 & 28.4 & - & 14.5 & 24.6 & 51.0 & 0.483 & 0.616 \\
\hline 濃褐 & 35.0 & 54.9 & 51.0 & 12.8 & 25.8 & 25.1 & 50.6 & 0.495 & 0.724 \\
\hline " & 33.0 & 80.4 & 75.0 & 22.5 & 33.0 & 30.0 & 44.0 & 0.683 & 0.746 \\
\hline 茶褐 & 35.0 & 53.1 & 56.1 & 14.7 & 20.1 & 26.5 & 35.8 & 0.732 & 0.887 \\
\hline 褐 & 41.5 & 34.4 & 30.7 & 10.7 & 13.7 & 35.2 & 44.6 & 0.781 & 0.937 \\
\hline " & 40.0 & 61.0 & 56.1 & 18.0 & 24.0 & 32.1 & 42.8 & 0.750 & 0.788 \\
\hline " & 40.0 & 72.4 & 70.8 & 22.0 & 28.1 & 31.1 & 39.7 & 0.783 & 0.856 \\
\hline 濃褐 & 37.0 & 65.2 & 65.6 & 24.2 & 20.6 & 36.9 & 31.4 & 1.175 & 1.450 \\
\hline " & 35.0 & 71.0 & 63.8 & 25.3 & 20.8 & 39.6 & 32.5 & 1.215 & 1.235 \\
\hline " & 38.0 & 38.0 & 32.1 & 15.7 & 9.2 & 49.0 & 28.6 & 1.707 & 1.290 \\
\hline$"$ & 37.0 & 57.1 & 56.2 & 22.2 & 16.8 & 39.6 & 29.9 & 1.322 & 1.350 \\
\hline " & 34.0 & 63.2 & 58.1 & 22.9 & 20.3 & 39.4 & 34.9 & 1.128 & 1.245 \\
\hline " & 40.0 & 74.9 & 74.0 & 38.0 & 11.0 & 51.4 & 14.9 & 3.460 & 1.515 \\
\hline$"$ & 39.0 & 42.1 & 44.0 & 22.5 & 5.0 & 51.2 & 11.4 & 4.499 & 2.050 \\
\hline$"$ & 38.0 & 44.2 & 73.6 & 21.2 & 8.4 & 28.8 & 11.4 & 2.512 & 3.200 \\
\hline$"$ & 36.0 & 69.3 & 63.3 & 32.1 & 14.5 & 50.5 & 22.9 & 2.208 & 2.060 \\
\hline$"$ & 34.0 & 80.0 & 88.7 & 37.0 & 17.0 & 41.6 & 19.2 & 2.170 & 2.064 \\
\hline$"$ & 34.0 & 79.9 & 87.0 & 34.0 & 20.2 & 39.1 & 23.2 & 1.695 & 1.980 \\
\hline
\end{tabular}

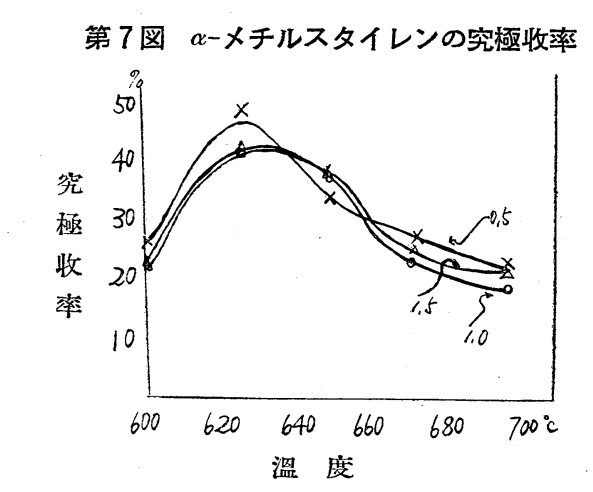

第 4 表 反応生成物の性状

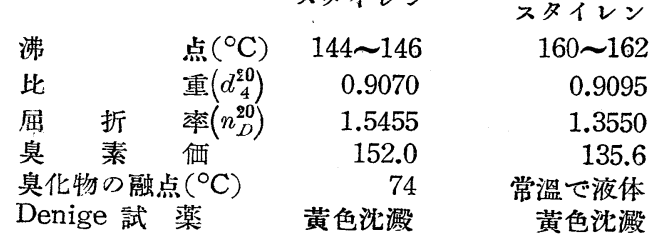

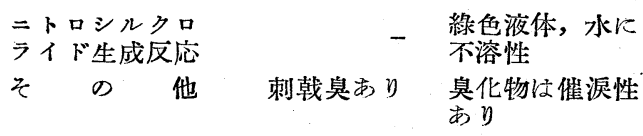

第 5 表 カオリン系触媒によるキュー メンの分解 (岩井氏)

\begin{tabular}{|c|c|c|}
\hline 触 & $\begin{array}{c}\text { スタイレン } \\
(\%)\end{array}$ & $\begin{array}{l}\alpha-x \text { チルスタ } \\
\text { イレン }(\%)\end{array}$ \\
\hline カオリン獟成体 & 32.2 & 8.1 \\
\hline $\begin{array}{l}\text { カオリン }(80) \text { 十酸化マグ } \\
\text { ネシウム }(20)\end{array}$ & 34.0 & 8.7 \\
\hline $\begin{array}{l}\text { カオリン } \\
(20)\end{array}$ & 37.1 & 8.9 \\
\hline $\begin{array}{l}\text { カオリン }(160)+ア ル ミ \\
(40)+\mathrm{KOH}(2)\end{array}$ & 39.5 & 9.3 \\
\hline カオリン $(80)+\mathrm{WO}_{3}(20)$ & 36.8 & 9.4 \\
\hline $\begin{array}{l}\text { カオリン }(160)+\mathrm{WO}_{3}(40) \\
+\mathrm{KOH}(2)\end{array}$ & 35.3 & 8.7 \\
\hline カオリン $(80)+\mathrm{Cr}_{2} \mathrm{O}_{3}(20)$ & 34.6 & 7.8 \\
\hline
\end{tabular}




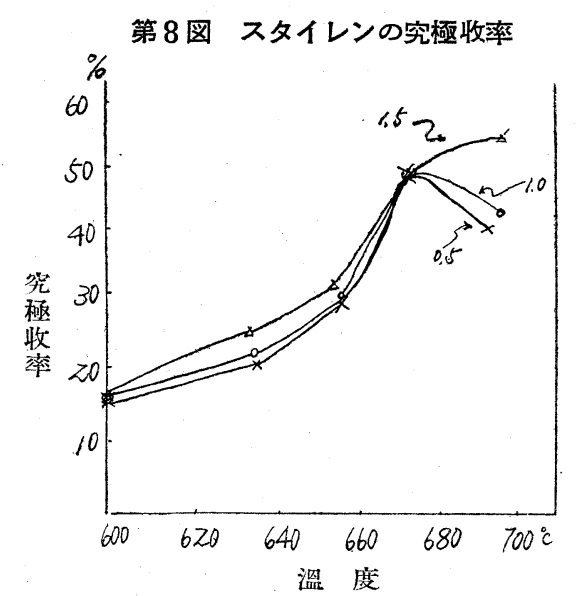

\section{VII. 総 括}

銅ーク口ム触媒を用い $500 \sim 700^{\circ} \mathrm{C}$ に抢いて 300〜 $500 \mathrm{mmHg}$ の減圧下でキューメンを分解した結果,

（1）スダイレンの生成は温度の上昇とともに増大 するのに対し， $\alpha$-メチルスタイレンのそれは 630〜 $650^{\circ} \mathrm{C}$ で最高值を示し, それ以後は温度の上昇ととも に減少した。そしてスタイレンは $700^{\circ} \mathrm{C}$ で 51.4\%， ג゙ーチルスタイレンは $630^{\circ} \mathrm{C}$ で $51.0 \%$ の最高収率 を示した。

（2）スタイレンと $\alpha$-メテルスダイレンとの分析 法としてはブロマイド法が最適であることを示した。

(3) 工業的にスタイレン拈び $\alpha$ ーメテルスタイ レンを主として生成させる場合の最適條件は次のごと くである。

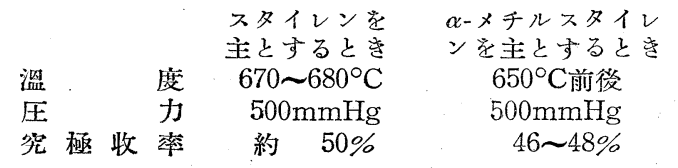

\section{（その 2） pーサイメンの接触分解}

著者らは銅ークロム触媒を用い土チルルンゼンを減 圧下で脱水素して良好な収率を以てスタイレンを得3， またこの法をキューメンの接触分解に応用し，スタイ レンおよび $\alpha$ メチルスタイレンの生成に適当な條件 灰(その1)に述へた。

一般に銅ークロム触媒は脱水素反応を撰択的に促進 する性質を有し，この点カオリン触媒と異つている。

本報はこの方法をさらに $p$-サイメンの接触分解に 匛用した場合の結果について述へたものである。

$p$-サイメンの熱分解においては次の 2 つの反応が 扎こり得尚。
(1)

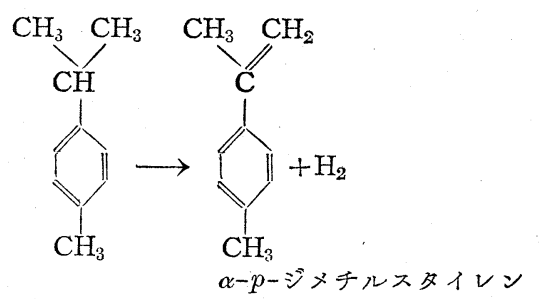

(2)<smiles>C=CC=Cc1cc(C)ccc1C=C</smiles>

pーサイメンはトルエンと石油分解ガス中のプロピ レンと走硫酸の存在の下に反応させるときに容易に得 られ ${ }^{1)}, \alpha-p$-ジメチルスタイレンは近時ブタジェンを とも重合すると抗張才の点で GR-S ゴムに勝り5),ま た $p$-メチルスタイレン重合物はスタイレンより重合 度が低く機械的強度はポりスタイレンより劣るが6)， 合成樹脂材粼として今後益々重要性がましつつある。 p-サイメンよりの $\alpha-p$-ジメチルスタイレンの合成 については Balandin がスタイレン合成用触媒で $\mathrm{CO}_{2}$

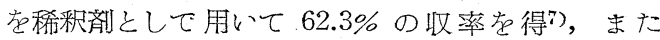
Kobe 抢よび Robert はクロムーアルミナ触媒を用い 80\% の収率を得ている5)。またパラサイメンの脱メ タンについては Ostrominslenski および Shepard の 特許8)があり，わが国では岩井氏は $650^{\circ} \mathrm{C}$ で無触媒 で29.5\% アドッール触楪で $35 \%$ の収率で $p$-メチ ルスタイレンを得ている2。

著者らは銅一クロ公触媒を用い，600 700 ${ }^{\circ} \mathrm{C}$, 減压 下で $p$-サイメン在接触的に分解し，その結果 $\alpha-p-$ ジメチルスタイレンの最高収率は $72 \%, p$-メチルス タイレンのそれは 29\%で，両者の和は大体 41〜77 \%であつた。

\section{I. 原料 p-サイメン}

トルエンと石油分解ガスとから硫酸の存在の下に合 成して得たもので，濃硫酸で着色しなくなるまで洗涤 し，水洗乾燥して再蒸溜した。その物理的性状は次の ごとくである。

$$
\begin{array}{ll}
\text { b.p. } & 176 \sim 176.6^{\circ} \mathrm{C} \\
n_{D}^{20} & 1.4906 \\
\text { 臭素価 } & 1 \text { 以下 }
\end{array}
$$

\section{II. 実験裝置, 方法, 触媒}

これらはエチルベンゼンの脱水素を行つた場合3)と ほほ同じものである。 


\section{III. 分析方法}

生成物は $\alpha-p$-ジメチルスタイレン, $p$-メチルスタ イレン，末反応の $p$-サイメン，少量の $p$-キシレン， トルエン抽びタール，重合物を含んでいる。これ觉 常圧の下に蒸溜するとその閒に重合がおこるので 10 $\mathrm{mmHg}$ の減圧蒸溜法を用いた。これによりタール重 合物は残椬として除かれ，またトルエン，キシレンな ぞは低沸点分として取除かれ，結局溜出分は $\alpha-p-シ ゙$ メチルスタイレン，p-メチルスタイレンおよび $p$-サ イメンの混合物となる。

この溜出分につき次のごとくして臭素価および Elliot 法による分析を行い，その組成を決定した。

（A）臭素価：溜出油 $0.1 \mathrm{~g}$ 前後を精科し，これを $10 \mathrm{cc}$ のクロロホルムにとかす。次に臭素の $2 \%$ 醋酸 溶液を徐々に加えて着色したとき，10\%沃度カリ溶液 を加え，過剩の臭素により遊離した沃素を $0.1 \mathrm{~N}$ チオ .硫酸》ーダで淈粉を指示薬として滴定した。

(B) Elliot 法4)：これは次の原理に基くもので， 両者の塩酸附加物の加水分解の難易により定量す 当。<smiles>CC(=CC1CCCC1C(C)(C)O)c1ccc(C)cc1</smiles><smiles>C=Cc1ccc(C)cc1</smiles>

すなわち加水分解されるものは第 3 級の炭素につい ている嫶素のみである。ここに遊離した塩酸をアルコ ール性葫性カリで滴定する。操作方法を示すと, 前記 の溜出試料 0.5 1.0g を精科し, ぶンゼン $25 \mathrm{cc}$ にと かしこれに乾いた塩酸がスを $30 \mathrm{~min}$ 吹込さ。次に 窒素ガスを $30 \mathrm{~min}$ 通じて未反応の塩化水素を追出す。 次に食塩-氷の混合物で $10 \mathrm{~min}$ 冷却, これに前以て冷 した $80 \%$ アルコールを $40 \mathrm{cc}$ 扣えて数秒閒振る。次

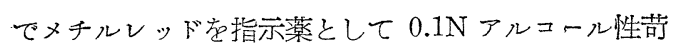
性カリて滴定し, 黄色の $30 \mathrm{sec}$ 持続する点を終点とす る。

以上の值を用いて次のごとくにして各成分を定量す る。

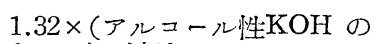

$$
\begin{aligned}
& \mathrm{A}(\%)=\frac{\text { factor }) \times \text { 滴定 } \mathrm{cc}}{\text { 試料量 }(\mathrm{g})} \\
& \mathrm{B}(\%)=\left(\text { 臭素洒 }-\frac{136}{132} \times \mathrm{A}\right) \times \frac{118}{160} \\
& \mathrm{C}(\%)=100-(\mathrm{A}+\mathrm{B})
\end{aligned}
$$

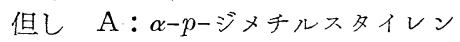

$$
\begin{aligned}
& \mathrm{B}: p \text { ×チルスタイレン } \\
& \mathrm{C} \text { : 未反応 } p_{\text {まサイメン }}
\end{aligned}
$$

また変化率は用いた $p$ ーサイメンから減圧溜出分中 の未反応 $p$-サイメンを差引以て暲した wto, 収

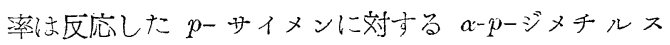
タイレンおよび $p$ メチルスタイレンの wto である。

\section{IV. 実験結果}

内径 $2.2 \mathrm{~cm}$ 長さ $1 \mathrm{~m}$ の石英管㕝用心成型した銅一 クロム鰠媒 $92 \mathrm{~g}$ (94cc) 老用い, 毎回 p-サイメン $30 \mathrm{cc}(2.58 \mathrm{~g})$ を用いて行つた結果は第 6 表!二示方ごと くである。

但し予備実験により $600 \sim 700^{\circ} \mathrm{C}$, L.S.V. (液空 䦎速度) $0.3 \sim 1.6$ 程度, 減圧度 $500 \mathrm{mmHg}$ の條件が よいことがわかつたので，この範囲の條件で実験劣行 つた。

第 6 表 銅-クロム触媒による $p^{-}$ サイメンの接触分解

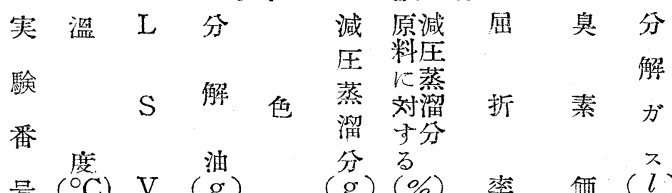

$\begin{array}{lllllllllll}8 & 610 & 1.9 & 25.3 & \text { 淡黃 } & 23.6 & 91.5 & 1.5005 & 23.2 & 0.7\end{array}$

$\begin{array}{llllllllll}9 & 600 & 0.9 & 25.1 & \text { " } & 23.5 & 91.1 & 1.5075 & 43.7 & 2.1\end{array}$

$\begin{array}{lllllllllll}10 & 600 & 0.8 & 24.7 & \Rightarrow & 23.0 & 89.2 & 1.4982 & 19.7 & 0.6\end{array}$

$\begin{array}{lllllllllll}11 & 600 & 0.7 & 24.0 & \Rightarrow & 22.4 & 86.8 & 1.5089 & 45.0 & 3.2\end{array}$

$\begin{array}{lllllllllll}12 & 600 & 0.3 & 23.5 & \Rightarrow & 22.7 & 88.0 & 1.5090 & 45.8 & 3.4\end{array}$

$\begin{array}{llllllllll}13 & 630 & 1.6 & 25.1 & 23.6 & 91.4 & 1.4991 & 19.3 & 0.8\end{array}$

$\begin{array}{llllllllll}14 & 630 & 1.2 & 24.6 & 23.4 & 90.6 & 1.5054 & 37.1 & 1.6\end{array}$

$\begin{array}{llllllllll}15 & 630 & 1.0 & 24.3 & \text { \% } & 23.0 & 89.2 & 1.5049 & 32.1 & 1.3\end{array}$

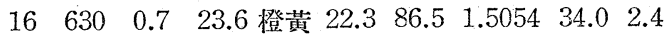

$\begin{array}{llllllllll}17 & 630 & 0.3 & 23.3 & \text { 橙 } & 22.0 & 85.2 & 1.5140 & 54.7 & 2.9\end{array}$

$\begin{array}{llllllllll}18 & 650 & 1.5 & 25.0 & \Rightarrow & 23.5 & 91.1 & 1.5049 & 32.8 & 1.3\end{array}$

$\begin{array}{lllllllllll}19 & 650 & 1.2 & 24.8 & 23.3 & 90.3 & 1.5054 & 37.0 & 1.9\end{array}$

$\begin{array}{llllllllll}20 & 650 & 1.0 & 24.3 & \Rightarrow & 22.9 & 88.7 & 1.5125 & 52.4 & 2.5\end{array}$

$\begin{array}{lllllllllll}21 & 650 & 0.6 & 23.8 & \text { ～} & 21.9 & 84.9 & 1.5130 & 54.4 & 2.9\end{array}$

$\begin{array}{llllllllll}22 & 650 & 0.3 & 21.8 & \text { 赤 } & 19.5 & 75.2 & 1.5166 & 59.8 & 3.8\end{array}$

$\begin{array}{llllllllll}23 & 670 & 1.5 & 24.8 & \text { 橙 } & 23.4 & 90.6 & 1.5050 & 33.8 & 1.7\end{array}$

$\begin{array}{llllllllll}24 & 670 & 1.3 & 23.9 & \Rightarrow & 22.1 & 85.6 & 1.5109 & 47.0 & 1.9\end{array}$

$\begin{array}{llllllllll}25 & 670 & 0.7 & 23.5 & \Rightarrow & 20.8 & 80.5 & 1.5159 & 56.6 & 4.1\end{array}$

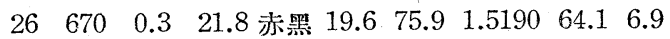

$\begin{array}{lllllllllll}27 & 700 & 1.5 & 23.8 & \Rightarrow & 21.0 & 81.4 & 1.5139 & 51.5 & 2.8\end{array}$

$\begin{array}{lllllllllll}28 & 700 & 1.2 & 22.5 & \Rightarrow & 18.7 & 72.5 & 1.5160 & 65.7 & 4.3\end{array}$

$\begin{array}{lllllllllll}29 & 700 & 0.6 & 20.4 & \Rightarrow & 15.4 & 59.7 & 1.5218 & 64.8 & 5.7\end{array}$

$\begin{array}{lllllllllll}30 & 700 & 0.3 & 19.5 & \Rightarrow & 14.8 & 57.4 & 1.5220 & 69.4 & 6.9\end{array}$ 
第 6 表より見得るように生成分解油は温度の上昇と ともに色が次第に濃くなり，一方減王蒸溜分の\%が減 少し, 逆に屈折率, 臭素価並にが ス生成量が増加す る。

第 6 表の代表的なものにつき，前記の方法でその組 成を分析し，变化率並に收率を竐算した結果は第 7 表 に示すごとくである。

\section{第 7 表 分解生成物の分析結果}

\begin{tabular}{|c|c|c|c|c|c|c|c|c|}
\hline & 㴘 & L & 減圧蒸 & & 変 & 收 & $(\%)$ & \\
\hline & & $\mathrm{S}$ & $\begin{array}{l}\alpha-p- \\
\Xi^{*} x\end{array}$ & $\begin{array}{l}p-x \\
\text { チ }\end{array}$ & 化 & & & \\
\hline & & & $\begin{array}{l}\text { チル } \\
\text { スタ }\end{array}$ & $\begin{array}{l}\text { スタ } \\
\text { イン }\end{array}$ & & $\begin{array}{l}\text { 于n } \\
\text { ス夕 }\end{array}$ & $\begin{array}{l}\text { ス夕 } \\
12\end{array}$ & \\
\hline & $\begin{array}{l}\text { 慶 } \\
\left({ }^{\circ} \mathrm{C}\right)\end{array}$ & $\mathrm{V}$ & $\begin{array}{l}\text { 1 } \\
\text { y }\end{array}$ & $\because$ & $\left(\begin{array}{l}\text { 率 } \\
(\%)\end{array}\right.$ & $\begin{array}{l}12 \\
y\end{array}$ & & \\
\hline 8 & 610 & 1.9 & 16.3 & 2.6 & 25.8 & 57.8 & 9.3 & 7 . \\
\hline 9 & 600 & 0.9 & 34.2 & 1.7 & 42.8 & 71.2 & 3.5 & \\
\hline 11 & 600 & 0.7 & 34.8 & 2.1 & 45.2 & 67.2 & 4.0 & \\
\hline 12 & 600 & 0.3 & 29.7 & 7.3 & 44.5 & 58.9 & 14.6 & \\
\hline 18 & 650 & 1.5 & 25.2 & 2.3 & 33.9 & 67.8 & 6.2 & \\
\hline 19 & 650 & 1.2 & 27.3 & 3.0 & 36.2 & 68.1 & 7.5 & \\
\hline 20 & 650 & 1.0 & 35.6 & 6.2 & 48.4 & 65.4 & 11.4 & \\
\hline 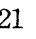 & 650 & 0.6 & 31.7 & 11.8 & 52.0 & 51.7 & 19.2 & \\
\hline 2 & 650 & 0.3 & 30.9 & 16.6 & 60.5 & 38.3 & 20.7 & \\
\hline 23 & 670 & 1.5 & 18.6 & 8.4 & 33.8 & 50.0 & 22.5 & \\
\hline 24 & 670 & 1.3 & 25.6 & 11.9 & 46.5 & 47.1 & 21.9 & \\
\hline 25 & 670 & 0.7 & 25.8 & 18.8 & 55.4 & 37.6 & 27.6 & \\
\hline 26 & 670 & 0.3 & 26.6 & 23.7 & 62.2 & 33.8 & 29.0 & \\
\hline 27 & 700 & 1.5 & 23.1 & 16.7 & 51.0 & 36.8 & 26.8 & \\
\hline 28 & 700 & 1.2 & 24.8 & 26.4 & 64.6 & 27.8 & 28.4 & \\
\hline 29 & 700 & 0.6 & 22.1 & 28.1 & 70.2 & 18.8 & 23.9 & \\
\hline 30 & 700 & 0.3 & 18.5 & 34.3 & 72.9 & 14.5 & 27.0 & \\
\hline
\end{tabular}

第 9 図 溫度之变化率との関係

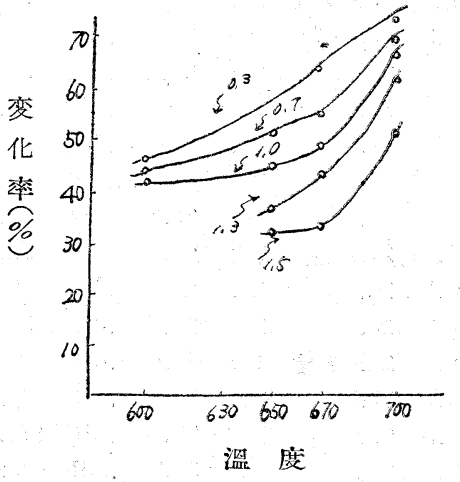

（図中の数字纹L.S.V.を示す）

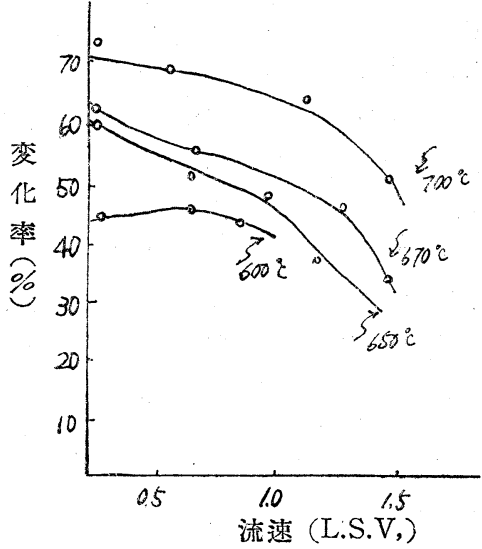

第10図

流速と变 化率との 関係

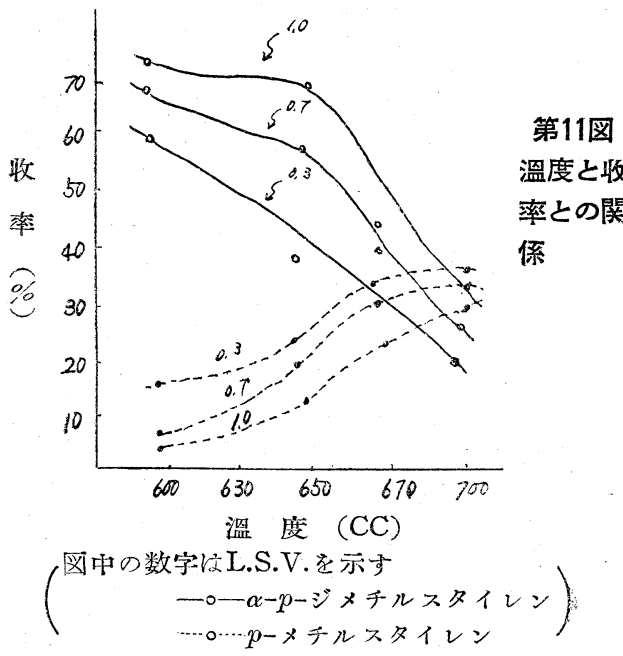

第12図 流速と收率との関係

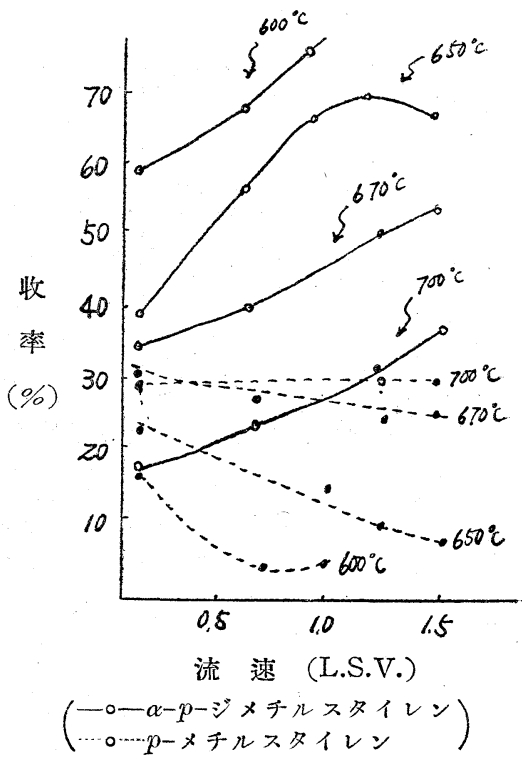




\section{$\mathrm{V}$. 実験結果の考察}

第6〜表の結果を変化率並に収率にわけて温度並に 流速 (L.S.V.) の影響を図示すれば次の第9〜12図のご とくになる。第 9〜10 図は変化率，第11〜12四は収率 の変化を示している。

まず第9〜10図をみると，温度の上昇とともに $p$ サイメンの変化率は堌大し，また同一温度では L. S. V. の大なる程減少する。特に温度の影響は 670 ７0 $0^{\circ} \mathrm{C}$ で著しい。

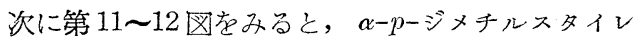
ンの生成は温度の上昇とともに減少するが， $p$ ーメチル スタイレンのそれは却つて増加している。同椂なこと は流速についても認められるところで，同一温度では $a$-pージメチルスタイレンの生成は L.S.V. の増加とと もに増大するのに対し，p-メチルスタイレンのそれは 却つて減少している。

すなわち $p$-サイメンの1次分解生成物市 $\alpha-p$-ジメ チルスタイレンで，温度の上昇とともにまた流速が少 さいすなわち接触時閒の増大とともにpーメチルスタ イレンに移行するものと思われる。

$\alpha$ - $p$-ジメチルスタイレンの最高収率は $600^{\circ} \mathrm{C} て ゙$ L.S.V. 0.9 のときで約 $72 \%$ を示した。また チルスタイレンの生成は 650 ～ $670^{\circ} \mathrm{C}$ 間で急激に增加 し，700年以上になると低下する傾向を示す。その最 高収率は $670^{\circ} \mathrm{C}$, L.S.V. 0.3 のとき得られ，29\% を 示した。

このような現象は前述のキューメンの接触分解によ る 合にも認められたところである。

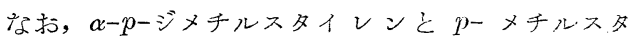
イレンの総収率流 $630 \sim 650^{\circ} \mathrm{C}$, L.S.V. 1.0 で最高值 走示し， 76\% であつた。

次に分解がスの組成は，温度の上昇とともに水素が 蔵少し，これに代つてメタンの生成が増加し，温度の

\section{第 8 表 分解ガスの組成}

L.S.V. $\frac{\text { 溫度 }}{\left({ }^{\circ} \mathrm{C}\right)}$

0.3600

$0.3 \quad 630$

$0.3 \quad 650$

$0.3 \quad 670$

$0.3 \quad 700$

$0.7 \quad 600$

$0.7 \quad 650$

$0.7 \quad 670$

$0.7 \quad 700$
分解ガスの組成 $(\%)$

$\overbrace{\mathrm{H}_{2}}^{\mathrm{CH}_{4}} \quad \mathrm{C}_{3} \mathrm{H}_{6} \quad \mathrm{C}_{2} \mathrm{H}_{4}$

$\begin{array}{llll}66.3 & 28.8 & 1.2 & 0.9\end{array}$

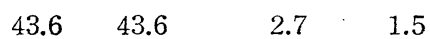

$\begin{array}{llll}49.6 & 41.9 & 2.4 & 1.2\end{array}$

$\begin{array}{llll}39.1 & 54.2 & 3.7 & 3.0\end{array}$

$\begin{array}{llll}40.2 & 49.5 & 3.7 & 4.5\end{array}$

$\begin{array}{llll}71.8 & 25.2 & 1.2 & 1.2\end{array}$

$\begin{array}{llll}49.4 & 44.1 & 3.2 & 1.9\end{array}$

$\begin{array}{llll}47.0 & 42.3 & 2.3 & 4.4\end{array}$

$\begin{array}{llll}38.5 & 52.1 & 3.7 & 4.3\end{array}$

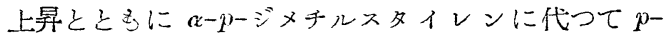
メチルスタイレンが増加军ること党示方。

第 8 表に代表的な場合の分解がスの組成を示す。

\section{Kobe ら5)の結果との比較}

Kobe らが $\mathrm{Cr}-\mathrm{Al}_{2} \mathrm{O}_{3}$ 触媒を用い， $482 \sim 593^{\circ} \mathrm{C}$ で p-サイメン定分解しているが，脱水素反応が圧倒的に おこり p-メチルスタイレンの最高收率は $10 \%$ 位で 西る。同し L.S.V. で著者らの結果と比較すると次の ごとくで， $\mathrm{Cr}-\mathrm{Al}_{2} \mathrm{O}_{3}$ 触媒よりも銅ークロム触媒の方 が脱水素性が優れていることがわかる。

L.S.V.

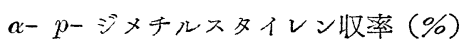

$\begin{array}{ccc} & \text { Kobe } ら\left(593^{\circ} \mathrm{C}\right) & \text { 著者ら }\left(600^{\circ} \mathrm{C}\right) \\ 1.0 & 65 & 74 \text { (外括值) } \\ 0.7 & 50 & 67 \\ 0.5 & 38 \text { (外插值) } & 63\end{array}$

\section{VII. 総 括}

銅-クロム触媒を用い， $500 \mathrm{mmHg}$ の減圧下で 600 $\sim 700^{\circ} \mathrm{C}$ で $p$-タイメンを分解し， $\alpha-p$-ジメチルスタ イレンと $p$-メチルスタイレンの生成に対する温度と 流速の影響党検した結果

（1）温度高く，流速小なる程分解率は大で，分解 油の色は次第に濃くなり, 屈折率, 臬素価も增大す る。

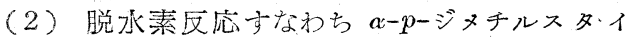
レンの生成は $600^{\circ} \mathrm{C}$ 附近の比較的低温度で抽り, 流速は大なる程よい。 $600 \sim 650^{\circ} \mathrm{C}, \mathrm{L}$. S, V. 0.9 1.5 でさその収率は 68〜72\% である。

(3) 脱メタン区応すなわわ $p$-メチルスタイレン の生成は $670^{\circ} \mathrm{C}$ 附近の比較的高温度で赫こり, 流速 は小なる方がよい。 $670 〜 700^{\circ} \mathrm{C}$, L.S.V. 0.3 で27〜29 \%の收率を示した。

（4）銅ークロム触媒は脱タタン反応よりも脱水素 用として優れている。

（5）分解分スの組成は温度の上昇とともにまた流 逥の小なる程, 水素の含有量が減少し, メタンのそれ が増加与る。これは(2)，(3)の結果と定性的に一致 する。

\section{交献}

1) 堤繁, 第 4 回触媒討論会特輯号(第12輯)

2）岩井信次，熱分解に上るスチロール同族体の合成 (誠文堂新光社, 昭24.10月発行)

3) 堤繁, 鹤崎正宸, 燃燒法, 34, 150 (1955).

4) J. H. Elliot \& E. Cook, Ind. Eng, Chem., Anal. Ed., 16, 20 3(1944) 
5) K. A. Kobe \& R. T. Romans, Ind. Eng. Chem., 43, 1755 8 (1951).

6）松非悅造，工化誌，44, 168 (1939).
7) Egloff, "Reaction of Pure Hydrocarbon"

8) I. Ostrominslenski \& M. G. Sphepard, Ohemo Abst., 10, 3492 (1925).

\section{Catalytic Cracking of Alkylbenzenes.}

By Shigeru Tsustumi, Hisashi Akatsuka, Yasuo Morimura \& Koji Taga

(Dept. of Applied Chemistry, Osaka University)

SYNOPSIS :- ( I ) On the Catalytic Cracking of Cumene under Reduced Pressure.

We have dehydrogenated ethylbenzene with copper-chromite catalyst at $500-700^{\circ} \mathrm{C}$ under reduced pressure and obtained 50-60\% yields of styrene per pass. The same method was applied to the catalytic cracking of cumene. The possible products by the cracking of cumene are benzene, styrene and $\alpha$-methylstyrene. The analysis of styrene and $\alpha$-methylstyrene was carried out by the bromide method. Styrene was determined in a form of styrene dibromide and the amount of $\alpha$-methylstyrene was calculated as a difference between the amounts of styrene, estimated by the amounts of dibromide, and those of vinyl compounds determined by the bromine number of the tar free products.

Although kaolin catalyst is reported to produce mainly styrene, copper-chromite catalyst produced mainly $\alpha$-methylstyrene, acting as a dehydrogenating catalyst at lower temperature.

The optimum" conditions for the formation of styrene and $\alpha$-methylstyrene were confirmed to be as the followings:

$\begin{array}{lcr} & \text { styrene } & \alpha \text {-methylstyrene } \\ \text { Temp. }\left({ }^{\circ} \mathrm{C}\right) & 670-680 & \text { ca.650 } \\ \text { Press. }(\mathrm{mmHg}) & 500 & 500 \\ \text { Ultimate Yield }(\%) & \text { ca.50\% } & 46-48 \%\end{array}$

The combined yields of styrene and $\alpha$-methylstyrene were up to $75 \%$.

(II) On the Catalytic Cracking of $p$-Cymene.

The reduced pressure method by the use of copper-chromite catalyst, developed in our laboratory, was successfully applied to the dehydrogenation of ethylbenzene as well as to the preparation of $a$-methylstyrene and styrene from cumene. This report deals with the application of this method to the catalytic craickng of $p$ cymene.

The reacting conditions selected in this experiment were temperature: $600-700^{\circ} \mathrm{C}$. L.S.V.: 0.3-1.6, pressure: $500 \mathrm{mmHg}$.

The possible products from the cracking of $p$-cymene are $\alpha$-p-dimethylstyrene and $\rho$-methylstyrene. The composition of the reaction product has been determined by the bromine number of the reaction product and the analytical method according to Elliot. Elliot method is based on the difference in the rate of hydrolysis of $\mathrm{HCl}$ addition compounds of $\alpha$-p-dimethylstyrene and $p$-methylstyrene.

The products obtained by the cracking of $p$-cymene were first distilled under a reduced pressure of about $10 \mathrm{mmHg}$ to remove volatile matters, such as benzene, toluene and xylene, and also tarry products. The distillates obtained were then 
subjected to bromine number determination and Elliot analysis.

The yield of $\alpha$-p-dimethylstyrene was maximum at a lower temperature of $600^{\circ} \mathrm{C}$ and a higher rate of 0.9 , whereas that of $p$-methylstyrene was increased with the rise in the temperature and with the decrease in the flow rate of $p$-cymene.

The optimum conditions for the formation of $\alpha$-p-dimethylstyrene and $p$-methylstyrene are as the followings:

$$
\alpha \text {-p-dimethylstyrene }
$$

Temp. $\left({ }^{\circ} \mathrm{C}\right)$

L.S.V.

Maximum yield (\%)
600

$$
p \text {-methylstyrene }
$$

29

Copper-chromite catalysts acted as a superior dehydrogenation' catalyst for the cracking of cumene and $p$-cymene in producing $\alpha$-methylstyrene and $\alpha$ - $p$-dimethylstyrene respectively. The formation of hydrogen was active at a lower temperature, but with a rise in the temperature, hydrogen was gradually replaced by methane, this is being coincided with the fact that the formation of $\alpha$-p-dimethylstyrene is predominant at a lower temperature, whereas that of $p$-methylstyrene at a higher temperature.

The comparison of our results with those of Kobe [Ind. End. Chem., 43, 1755. (1955)] is given hereunder:

Yield of $\alpha$-p-dimethyscyrene (\%)

$\begin{array}{ccc}\text { L.S.V. } & \text { Kobe }\left(\mathrm{Cr}-\mathrm{Al}_{2} \mathrm{O}_{\llcorner} \text {Cat. }\right) & \text { Authors }\left(\mathrm{Cu}-\mathrm{Cr}_{2} \mathrm{O}_{4} \text { Cat. }\right) \\ 1.0 & 65 & 74 \\ 0.7 & 50 & 67 \\ 0.5 & 38 & 63\end{array}$

\section{第 22 回コークス特別開催予告}

すで怙知らせ致しましたよう飞，来る3月 $29,30,31$ 日の 3 日間日本鉱業会館講堂

（東京都中央区銀座西 8 の）飞おいて第22回コークス特別会を開催致しますから， 多数の御発表並びに御参加を御願い致します。日程は下記のと抢りであります。

3 月29日（木）研究発表会

3 月30日（金）研究発表会

3月31日（土）見学会（資源技術試験所） 